S. Afr. J. Agric. Ext.

Vol. 44, No. 2, 2016: 248 - 255

Msuya \&

Wambura.

DOI: http://dx.doi.org/10.17159/2413-3221/2016/v44n2a431

(Copyright)

\title{
FACTORS INFLUENCING EXTENSION SERVICE DELIVERY IN MAIZE PRODUCTION BY USING AGRICULTURAL INNOVATION SYSTEM IN MOROGORO AND DODOMA REGIONS, TANZANIA.
}

\author{
Msuya, C. P. ${ }^{53}$ \& Wambura, R. M. ${ }^{54}$ \\ Correspondence Author: Prof. Catherine Msuya, Email: cat_Msuya@yahoo.com
}

\section{ABSTRACT}

Conventional extension system in Tanzania has recorded limited success in improving agricultural productivity including maize production in the country. The Agricultural Innovation System (AIS) approach in extension service delivery deemed desirable in addressing the challenge. However little is known about the factors influencing delivery of extension service by using AIS. A study was conducted in Morogoro and Dodoma Regions to investigate the identified gap. A cross sectional research design was used to collect data from 345 respondents randomly selected from a population of various actors involved in the maize value chain. Key informant interviews and Focus group discussions were also used in data collection. Observations were used to supplement the collected information. The collected quantitative data were analyzed by using the Statistical Package for Social Science computer program while content analysis was used to analyze the qualitative data. The study findings show that factors influencing performance of extension service delivery include Extension staffs' inadequate knowledge and skills on providing advice by using Agricultural Innovation System. Others were availability, affordability, efficiency, relevance and costs of extension service delivery. Based on the study findings it is concluded that despite the relevance of AIS over conventional extension system, there are a number of factors influencing delivery of extension service using AIS that might in turn bring effect on maize production the study areas. It is therefore recommended that negative factors should be addressed for effective performance of the system to improve maize production.

Keywords: Extension service delivery, Agricultural Innovation System approach (AIS), Maize production.

\section{INTRODUCTION}

In Tanzania agricultural extension advisory service is regarded as one of the main drivers to agricultural production and productivity. However, conventional extension system has recorded limited success in improving agricultural productivity including maize production in the country. Maize ranks first among the major cereal grains grown in Tanzania and the main staple food for the entire population. The crop is mainly grown by smallholder farmers on 1-3 ha holdings accounting for about $85 \%$ of the total crop production (URT, 2007). Nearly twothirds of Tanzanian farmers are engaged in maize production, therefore broad pro-poor growth can be achieved by targeting maize productivity. Although maize is the main staple crop, yield levels are still low. According to Mwanga (2010) the national maize yield growth rate is $2.4 \%$ per annum, which is $0.3 \%$ less than the population growth rate. The average

\footnotetext{
53 Department of Agricultural Education and Extension, P. O. Box 3002, Sokoine University of Agriculture, Tanzania. Email: cat_Msuya@yahoo.com

${ }^{54}$ Department of Agricultural Education and Extension, P. O. Box 3002, Sokoine University of Agriculture, Tanzania.
} 
S. Afr. J. Agric. Ext.

Vol. 44, No. 2, 2016: 248 - 255

Msuya \&

Wambura.

DOI: http://dx.doi.org/10.17159/2413-3221/2016/v44n2a431

(Copyright)

national production is approximately 1.25 ton/ha instead of 4.5 ton/ha expected under good management practices (Kaliba, Verkuijl, Mwangi, Mwilawa, Anandajayasekeram, \& Moshi, 1998; FAOSTAT, 2014). In Morogoro and Dodoma Regions on-farm average yields range from 0.2 to 0.48 ton/ha (Mwanga 2010).

The problem of low maize production is partly attributed to the extension system working mainly with researchers and farmers while paying less attention to other actors in the maize innovation system (URT, 2010; URT, 2011). To address this weakness the use of Agricultural Innovation System (AIS) approach in extension service delivery deemed desirable (Spielman \& Birner, 2008). The AIS concepts and framework focus on the totality of actors needed to stimulate innovation and growth, and emphasizes the outcomes of knowledge generation and adoption. The framework captures not only the influence of market forces, but also the impacts of organizational learning and behavioural change, nonmarket institutions, and public policy processes. It highlights the importance of framework conditions and linkages to other sectors, and the broader science and technology (S\&T) community both within and outside the country. This framework also implicitly integrates the value-chain concept and in particular value chain actors (Spielman \& Birner, 2008). Several studies have investigated factors influencing the delivery of conventional extension system (Mack \& Fernandez - Baca, 2004; Akram, Pervaiz \& Ashraf 2003; Nkonya, Schroeder \& Norman, 1997). However little is known about the factors influencing delivery of extension service by using Agricultural Innovation System. The purpose of this paper is therefore to investigate the factors influencing delivery of extension service in maize production by using the Agricultural Innovation System in Morogoro and Dodoma Regions.

\section{METHODS AND DATA SOURCES}

A cross sectional research design was used to collect data from 346 respondents randomly selected from a population of various actors involved in the maize innovation system in Morogoro and Dodoma Regions. The interviewed actors were input suppliers, farmers, traders, processors, market intermediary, domestic wholesalers, government officials, technical specialists, financial institutions, farmers' organizations and transporters. Key informant interviews and Focus group discussion were also used in data collection. Observations were used to supplement the collected information. The collected quantitative data were coded, entered, cleaned and analyzed by using the Statistical Package for Social Science (SPSS) computer program. Frequencies and percentages were used to show the distribution of the study variable. Content analysis was used in analyzing qualitative data collected from focus group discussion and key informants interviews by employing thematic analysis. This is a method used to identify prominent themes related to the research objectives (Braun \& Clarke, 2006). Several stages were followed during the process of analysis. These included review of the collected data to check for their accuracy. This was followed by coding, identifying the themes related to the study objectives and collating all codes relevant to each theme. In addition, the project team members thoroughly reviewed the identified themes to check their validity in relation to the entire dataset ensuring that these were consistent with the project objectives.

\section{RESULTS AND DISCUSSION}

Various actors contacted identified several factors that influence the performance of extension service delivery and these include in-availability of adequate knowledge and skills on AIS. Others are availability of extension services, affordability, efficiency, relevance and 
S. Afr. J. Agric. Ext.

Vol. 44, No. 2, 2016: 248 - 255

Msuya \&

Wambura.

DOI: http://dx.doi.org/10.17159/2413-3221/2016/v44n2a431

(Copyright)

costs of extension service delivery. The subsequent sections provide a detailed description of each depicted factor.

\subsection{Inadequate knowledge and skill on AIS}

In order to improve agricultural production and productivity the innovation system should bring actors together in their desire to introduce or create novelty or innovation in the value chain, allowing it to respond in a dynamic way to an array of market, policy, and other signals. In other words, the innovation system should create knowledge and skills-based value addition to the value chain (World Bank, 2007).

During the focus group discussion and key informant interviews it was informed that most of the extension agents provide advice on maize production leaving other aspects in the chain like processing, marketing and consumption. They focus mostly on farmers (producers) and neglecting other actors in the innovation system and value chain in particular. It was further informed during the focus group discussion with officials in the Ministry of Agriculture that this problem is due to the fact that most of the extension staff was trained on agricultural production aspects and not the entire value chain and innovation system in general which limit them to provide service on the same. This implies that they use a conventional extension approach which is contrary to Spielman \& Birner, (2008) who suggest the use of Agricultural innovation system.

\subsection{Availability of extension services}

Agricultural extension service is one of the pre-condition for improving agricultural production (Isinika, Ngetti, Kimbi \& Rwambali, 2005). In realization of this most of the countries including Tanzania emphasize the availability of extension services to farmers and other actors involved in agricultural production and productivity. When various actors were asked to indicate factors influencing the performance of extension service delivery, availability of extension service was highlighted as one of the critical factors (Table 1).

Table 1: Availability of extension service

\begin{tabular}{|l|l|l|l|}
\hline Maize value chain Actor & Frequency $(\mathbf{n})$ & Percentage & Total (N) \\
\hline Input Suppliers & 9 & 45.0 & 20 \\
\hline Farmers & 77 & 57.0 & 135 \\
\hline Traders & 9 & 36.0 & 25 \\
\hline Processors & 8 & 33.3 & 24 \\
\hline Market intermediary & 7 & 41.2 & 17 \\
\hline Domestic retailers & 3 & 27.2 & 11 \\
\hline Government Officials & 5 & 20.8 & 24 \\
\hline Technical Specialist & 15 & 41.6 & 36 \\
\hline Financial Institutions & 7 & 43.7 & 16 \\
\hline Farmer's Organization & 1 & 14.3 & 7 \\
\hline Transporters & 10 & 32.2 & 31 \\
\hline
\end{tabular}

Table 1 shows that 77 (57.0\%) of 135 interviewed farmers indicated availability of extension services regarding maize production. Other actors who pointed out the availability of extension services were input suppliers 9 (45\%), financial institutions $7(43.7 \%)$ and technical specialists $15(41.6 \%)$. During the focus group discussion respondents were 
S. Afr. J. Agric. Ext.

Vol. 44, No. 2, 2016: 248 - 255

Msuya \&

Wambura.

DOI: http://dx.doi.org/10.17159/2413-3221/2016/v44n2a431

(Copyright)

requested to indicate sources of extension services. It was informed that most of them get advice from their colleagues and from input suppliers who provide some advice when purchasing inputs due to limited number of extension staff. This implies that the majority of respondents felt that extension service for maize production is not available. During the interview with key informants and focus group discussion with various actors, it was pointed out that generally the available extension service is not adequate and sometimes it is not available at all. It was highlighted that the inadequate extension service is attributed by lack or low number of extension staff. It was explained that there are villages, which have no extension agent to advise them on various aspects of agricultural production including maize production. Also in some areas one government extension agent is expected to serve various innovation system actors in the entire ward consisting of about 1,500 people, which becomes difficult for an agent to reach all actors including farmers. Due to this fact some actors use their own traditional ways of farming and other activities in the chain like processing. The findings are in accordance with (URT, 2007) which points out the problem of inadequate number of extension agents in the country. The indicated number of extension staff was expected to serve only farmers, but with the changing trend where extension staffs are required to deal with the entire innovation system, the number is definitely very low.

\subsection{Affordability of extension service}

In Tanzania extension service is provided by government (public) and private sectors (which are Non Governmental Organizations (NGOs), Community Based Organizations (CBOs), farmers associations, cooperative societies and farmers' networks, agribusinesses and religious organizations) (MAC, 2000). However the government remains the main provider of extension service in the country. Public extension service is largely provided for free while private extension service provided is in most cases charged. In addition public extension service is provided to small scale farmers who are the majority while private extension service is largely provided to medium and large scale farmers. However, small scale farmers are not restricted to public extension services. This implies that they can also access private extension services, so to can large and small scale farmers access public extension services. The respondents were requested to indicate whether available extension service was affordable and their responses are as summarized in Table 2.

Table 2: Affordability of extension service

\begin{tabular}{|l|l|l|l|}
\hline Maize value chain Actor & Frequency (n) & Percentage & Total (N) \\
\hline Input Suppliers & 1 & 5.0 & 20 \\
\hline Farmers & 36 & 26.6 & 135 \\
\hline Traders & 6 & 24.0 & 25 \\
\hline Processors & 6 & 25.0 & 24 \\
\hline Market intermediary & 5 & 29.4 & 17 \\
\hline Domestic retailers & 3 & 27.2 & 11 \\
\hline Government Officials & 3 & 12.5 & 24 \\
\hline Technical Specialist & 3 & 8.3 & 36 \\
\hline Financial Institutions & 2 & 12.5 & 16 \\
\hline Farmer's Organization & 1 & 14.3 & 7 \\
\hline Transporters & 3 & 9.6 & 31 \\
\hline
\end{tabular}

According to Table 2 less than $30 \%$ of each interviewed respondents indicated that extension service was affordable. This means that very few interviewed respondents felt that available 
S. Afr. J. Agric. Ext.

Vol. 44, No. 2, 2016: 248 - 255

Msuya \&

Wambura.

DOI: http://dx.doi.org/10.17159/2413-3221/2016/v44n2a431

(Copyright)

extension service is affordable especially the extension service provided by private sector. Inadequate extension service (as indicated in section 3.1) which is not affordable has a serious impact on agricultural production and productivity especially to a country like Tanzania that is largely depend in agriculture as a backbone of its economy.

\subsection{Efficiency of Extension service}

Over a number of years the extension system in Tanzania was co-ordinated by the Ministry of Agriculture, Livestock and Fisheries (MALF), the then Ministry of agriculture food security and cooperatives (MAFC). Under that arrangement the system was blamed by failing to serve its clients effectively. In order to improve effectiveness as well as efficiency of the system, extension was decentralized to the local government authorities. The main essence of decentralization was to improve efficiency of extension service delivery to local communities (URT, 2006). Although that was the case various actors interviewed mentioned efficiency as one of the factors that influence performance of extension service delivery in maize production as indicated in Table 3.

Table 3: Efficiency of Extension service delivery

\begin{tabular}{|l|l|l|c|}
\hline Maize value chain Actor & Frequency (n) & Percentage & Total (N) \\
\hline Input Suppliers & 7 & 35.0 & 20 \\
\hline Farmers & 9 & 6.6 & 135 \\
\hline Traders & 5 & 20.0 & 25 \\
\hline Processors & 1 & 4.1 & 24 \\
\hline Market intermediary & 1 & 5.8 & 17 \\
\hline Domestic retailers & 2 & 18.1 & 11 \\
\hline Government Officials & 7 & 16.7 & 24 \\
\hline Technical Specialist & 6 & 16.6 & 36 \\
\hline Financial Institutions & 3 & 18.8 & 16 \\
\hline Farmer's Organization & 1 & 14.3 & 7 \\
\hline Transporters & 13 & 41.9 & 31 \\
\hline
\end{tabular}

According to Table 3 very few respondents indicated that extension service delivery is efficient. Specifically the study findings show that about $13(42 \%)$ and $7(30 \%)$ of transporters and input suppliers, respectively indicated that extension service delivery is efficient. In addition less than $21 \%$ of the other interviewed actors indicated the same. This implies that despite of the decentralization, very few respondents perceived extension system as being efficient in delivering extension services to community members. This calls for the need of government to come up with strategies for improving extension efficiency. These include pin pointing all challenges that affect efficiency performance of the system and address them accordingly.

\subsection{Relevance of extension service}

It is widely accepted that availability of extension service is crucial for agricultural production and productivity. But the available service becomes useless if it is irrelevance to the needs of the community members. Based on this understanding, relevance of extension service delivered in maize production was another factor that was investigated in this study as indicated in Table 4. 
Table 4: Relevance of extension service

\begin{tabular}{|l|l|l|l|}
\hline Maize value chain Actor & Frequency (n) & Percentage & Total (N) \\
\hline Input Suppliers & 2 & 10.0 & 20 \\
\hline Farmers & 7 & 5.2 & 135 \\
\hline Traders & 3 & 12.0 & 25 \\
\hline Processors & 9 & 37.5 & 24 \\
\hline Market intermediary & 3 & 17.6 & 17 \\
\hline Domestic retailers & 2 & 18.1 & 11 \\
\hline Government Officials & 4 & 29.2 & 24 \\
\hline Technical Specialist & 3 & 8.3 & 36 \\
\hline Financial Institutions & 2 & 12.5 & 16 \\
\hline Farmer's Organization & 2 & 28.5 & 7 \\
\hline Transporters & 2 & 6.4 & 31 \\
\hline
\end{tabular}

Very few respondents indicated that extension service delivery is relevant (Table 3.4). The study findings show that only (9) $37.5 \%$ of 24 interviewed processors indicated that extension service delivery was relevant. On the other hand less than $30 \%$ of each other interviewed respondents namely government officials, farmers, traders and others indicated that delivered extension service is relevant. For example out of 135 farmers who were interviewed only $7(5.2 \%)$ indicated that extension service delivery was relevant. This implies that most of interviewed farmers did not see the relevance of extension service delivery. The irrelevance of extension service delivery indicated by the majority of farmers is of great concern taking into account that farmers are regarded as the main recipients of extension services. This calls the need for government to increase the number of extension staff with relevant knowledge and skills required to serve multi-actors in the agricultural production system.

\subsection{Cost of Extension Service delivery}

Any service rendered to the community has cost implications. This can be in terms of time, finance or labour. Cost of extension service delivery was therefore pointed by various actors as another factor that affects delivery of extension services on maize production and productivity to various actors (Table 5).

Table 5: Cost of extension service delivery

\begin{tabular}{|l|l|l|c|}
\hline Maize value chain Actor & Frequency (n) & Percentage & Total (N) \\
\hline Input Suppliers & 1 & 5.0 & 20 \\
\hline Farmers & 6 & 4.4 & 135 \\
\hline Traders & 2 & 8.0 & 25 \\
\hline Processors & 0 & 0.00 & 24 \\
\hline Market intermediary & 1 & 5.8 & 17 \\
\hline Domestic retailers & 1 & 9.1 & 11 \\
\hline Government Officials & 5 & 20.8 & 24 \\
\hline Technical Specialist & 9 & 25.0 & 36 \\
\hline Financial Institutions & 2 & 12.0 & 16 \\
\hline Farmer's Organization & 2 & 28.5 & 7 \\
\hline Transporters & 3 & 9.6 & 31 \\
\hline
\end{tabular}


S. Afr. J. Agric. Ext.

Vol. 44, No. 2, 2016: 248 - 255

Msuya \&

Wambura.

DOI: http://dx.doi.org/10.17159/2413-3221/2016/v44n2a431

(Copyright)

Very few interviewed respondents indicated low cost of extension services. For example only one respondent from each category of input suppliers, market intermediary and domestic retailers observed low cost of extension services to have influence on extension service delivery (to be low). Not a single processor observed the same. This implies that despite inadequate extension service which is not affordable it is also costly.

\section{CONCLUSIONS AND EXTENSION IMPLICATIONS}

Based on the study findings it is concluded that despite the relevance of AIS over conventional extension system, there are a number of factors influencing the delivery of extension service using AIS. This might in turn have an effect on maize production and productivity in the study areas. It is therefore recommended that the negative factors should be addressed for effective performance of the system to improve maize production.

\section{REFERENCES}

AKRAM, M., PERVAIZ, U. \& ASHRAF, H. 2003. Main factors Affecting Extension Activities: Case Study in Malakand Agency, Sarhad. Journal of Agriculture 19(1):163168.

BRAUN, V. \& CLARKE, V. 2006. Using thematic analysis in psychology. Qualitative Research in Psychology 3 (2): 77-101.

FAOSTAT. 2014. Performance of maize in Tanzania [https://www.google.co.tz/?gfe_rd=cr\&ei=L9RzVpXMI4ioQfx57TwBQ\&gws_rd=ssl\#q $=$ FAOSTAT\%2C+AUGUST+2014]. Site visited on 15.10.2015.

ISINIKA, A. C., NGETTI, M., KIMBI, G. G. \& RWAMBALI, E. G. 2005. Contemporary Challenges of Agricultural Advisory Services Delivery in Tanzania. Proceedings on the second National Agricultural Symposium in Tanzania. Institute of Continuing Education, SUA, Morogoro, Tanzania 24-25, February 2005. 13pp

KALIBA, A. R. M., VERKUIJL, H., MWANGI, W., MWILAWA, A. J. T., ANANDAJAYASEKERAM, P. \& MOSHI, A. J. 1998. Adoption of Maize Technologies in Central Tanzania. CIMMYT, Mexico. 29pp. Limbu, F. (1999). Agricultural technology: economic viability and poverty alleviation in Tanzania. Paper presented at the Structural transformation policy workshop. Nairobi: ECAPAPA. Tegemeo Institute and Michigan State University.

MACK, S. D. \& FERNANDEZ - BACA, S. 2004. Strategies for effective extension services to guide the advancement of animal agriculture in Developing countries.

MAC. (MINISTRY OF AGRICULTURE AND COOPERATIVES). 2000. The need for Agricultural Extension Reform in Tanzania (1) Review of Literature. MAC-Extension Facilitation Unit, Dar es Salaam

MWANGA, L. J. 2010. Transfer and utilization of agricultural production innovations in Tanzania. A Dissertation for Award of Masters of Arts in Rural Development Degree at Sokoine University of Agriculture, Morogoro, Tanzania.

NKONYA, E., SCHROEDER, T. \& NORMAN, D. 1997. Factors Affecting Adoption of improved seed and fertilizer in Northern Tanzania. Journal of Agricultural Economics, 18:1-12.

SPIELMAN, D. \& BIRNER, R. 2008. How innovative is your agriculture? Using Innovation indicators and benchmarks to strengthen national agricultural innovation systems. The World Bank: Washington, DC.

[http://www.future-agricultures.org/farmerfirst/files/T2b_van_Mele.pdf]. Site visited on 13.11.2015. 
S. Afr. J. Agric. Ext.

Vol. 44, No. 2, 2016: 248 - 255

Msuya \&

DOI: http://dx.doi.org/10.17159/2413-3221/2016/v44n2a431

Wambura.

URT (UNITED REPUBLIC OF TANZANIA). 2006. Ministry of Livestock Development, National Livestock Policy, Government Print.

URT (UNITED REPUBLIC OF TANZANIA). 2007. Improved Agricultural Technologies Recommended in Tanzania. The Department of Research and Training. Ministry of Agriculture Food Security and Cooperatives, Dar es Salaam 144pp.

URT (UNITED REPUBLIC OF TANZANIA). 2010. National Strategy for Growth and Reduction of Poverty II (NSGRP II). Draft, MAFC, Dar-es-Salaam. March 28, 2010.

URT (UNITED REPUBLIC OF TANZANIA). 2011. National Agricultural Policy. Final Draft, MAFC, March 2011, Dar-es- Salaam. 30pp.

WORLD BANK. 2007. World Bank Participation Source Book. [www.world bank.org/source book] site visited on 29.10.2015. 